\title{
UPAYA MENINGKATKAN PENGUASAAN MATERI LOGARITMA \\ MELALUI MODEL PEMBELAJARAN KOOPERATIF TIPE THINK PAIR SHARE PADA SISWA KELAS X SMA NEGERI 1 SUNGAI RAYA
}

\author{
Rufini \\ SMAN 1 Sungai Raya \\ rufini_pipin@yahoo.com
}

\begin{abstract}
Efforts to improve themastery of logarithm through cooperative learning model think pair shareatclass X students of SMA Negeri 1 Sungai Raya. The purpose of this study was to describe the effort to improve the mastery of logarithm through cooperative learning model think pair share in class X SMA Negeri 1 Sungai Raya. The method used was Classroom Action Research conducted by 2 cycles with a purpose to get good study planning, implementation and up can improve result learn student in comprehending logarithm items at study of mathematics. With the descriptive method of data collector that is used is a matter of observation and test sheets . Result of from this research is from condition of early to condition of first cycle its improvement equal to $19,8 \%$, and from condition of first cycle to condition of second mount equal to 13,3\%. Becoming from condition of early to condition of second mount equal to $35,7 \%$. This means that there has been a increasedthe mastery of logarithm through cooperative learning model think pair shareatclass $X$ students of SMA Negeri 1 Sungai Raya.
\end{abstract}

Keywords: $\quad$ Improve math skills,material logarithm, cooperative learning model think pair share.

\begin{abstract}
Kajian kebijakan Depdiknas tahun 2007 tentang kurikulum matematika menerangkan bahwa matematika harus dipelajari siswa karena kegunaan yang penting dalam kehidupan bangsa Indonesia. Penerapan matematika akhir-akhir ini telah banyak berubah dan cepat, karena kehadiran dan perkembangan teknologi elektronik dalam dunia kerja. Melihat kenyataan ini kurikulum pembelajaran matematika bertujuan mempersiapkan siswa tidak hanya untuk melanjutkan ke
\end{abstract}

pendidikan tinggi tetapi juga untuk memasuki dunia kerja.

Pembelajaran Matematika umumnya didominasi oleh pengenalan rumus-rumus serta konsep-konsep secara verbal, tanpa ada perhatian yang cukup terhadap pemahaman siswa. Disamping itu proses belajar mengajar hampir selalu berlangsung dengan metode "chalk and talk" guru menjadi pusat dari seluruh kegiatan di kelas, padahal menurut Trianto (2010:103) siswa menghadapi kesulitan 
memahami konsep-konsep matematika saat mereka diajar dengan metode tradisional atau dalam hal ini yaitu "chalk and talk". dimana pemahaman konsep-konsep tersebut sangatlah perlu saat mereka berhubungan dengan dunia kerja.

Dari pengalaman peneliti dalam memberikan pembelajaran matematika kepada siswa selama ini, sebagian besar siswa sulit memahami materi logaritma. Meskipun peneliti sudah berupaya membimbing siswa dalam memahami konsep logaritma, namun hasil belajar siswa belum sesuai dengan yang diharapkan, yaitu masih banyak siswa yang nilainya kurang dari standar ketuntasan belajar minimal. Saat dilakukan wawancara langsung terhadap beberapa siswa mengenai apa yang menjadi kendala mereka dalam menguasai materi logaritma, mereka rata-rata menjawab bingung dalam menerapkan sifat-sifat logaritma. dalam penelitian Nikmah diperoleh hasil bahwa sebanyak 50,5\% siswa saat menyelesaikan soal logaritma salah dalam penerapan sifat-sifat logaritma (Asep, 2011:8). Hal ini disebabkan cara belajar di kelas yang kurang efektif yang terpusat kepada guru, siswa lebih pasif dalam belajar dan pembelajaran yang dilakukan menjadi kurang bermakna. Maka dari itu dibutuhkan model pembelajaran yang dapat membuat siswa lebih aktif dalam pembelajaran di kelas.

Dalam upaya meningkatkan hasil belajar siswa pada materi logaritma, peneliti memilih model pembelajaran kooperatif tipe ThinkPair-Share (TPS) pada pembelajaran matematika untuk diterapkan. Karena model pembelajaran kooperatif tipe Think-Pair-Share
(TPS) memiliki kelebihan antara lain ; (1) memberi waktu lebih banyak pada siswa untuk berfikir, menjawab dan saling membantu satu sama lain, (2) lebih mudah dan cepat pembentukan kelompoknya, siswa lebih aktif dalam pembelajaran karena satu kelompok hanya terdiri dari dua siswa (Fadholi, 2009).

Berdasarkan uraian tersebut, perlu diadakan penelitian tindakan kelas tentang "Upaya Meningkatkan Penguasaan Materi Logaritma Melalui Model Pembelajaran Kooperatif Tipe Think pair share Pada Siswa Kelas X SMA Negeri 1 Sungai Raya". Dengan serangkaian tindakan, mulai dari perencanaan, pelaksanaan, sampai dengan evaluasi, diharapkan dapat meningkatkan pemahaman siswa pada materi logaritma. Adapun tujuan dalam penelitian ini yaitu ; (1) Mendeskripsikan pelaksanaan penelitian tindakan kelas dalam upaya meningkatkan penguasaan materi logaritma melalui model pembelajaran kooperatif tipe think pair share pada siswa kelas X SMA Negeri 1 Sungai Raya (2) Mendeskripsikan aktifitas belajar penelitian tindakan kelas dalam upayameningkatkan penguasaan materi logaritma melalui model pembelajaran kooperatif tipe think pair share pada siswa kelas X SMA Negeri 1 Sungai Raya (3) Mendeskripsikan hasil belajar penelitian tindakan kelas dalam upaya meningkatkan penguasaan materi logaritma melalui model pembelajaran kooperatif tipe think pair share pada siswa kelas X SMA Negeri 1 Sungai Raya. Matematika merupakan pengetahuan yang kebenarannya 
bersifat deduktif, kebenaran matematika merupakan kebenaran koherensi atau konsisten, matematika dapat dipandang baik sebagai produk maupun proses berfikir. Karakteristik pembelajaran matematika menurut Sumardyono (2004:47) sebagai berikut : (1) Karakteristik kultural matematika dapat dilihat pada tiga hal ; (a) Sejarah matematika, (b) evolusi matematika, dan (c) ethnomatematika. Implikasi penggunaan karakteristik kultural dalam pembelajaran matematika terdapat pada tiga aspek ; (a) pemahaman, (b) antusiasme, dan (c) keterampilan. (2) Karakteristik filosofis matematika dapat dilihat pada tiga aliran utama, yaitu formalism, logisisme atau logikalisme, dan intuisionisme. Pengaruh landasan matematika dalam pembelajaran harus sesuai dengan tujuan pendidikan matematika. (3) Karakteristik umum matematika meliputi beberapa hal ; (a) memiliki kajian objek yang abstrak, berupa fakta, operasi (relasi), konsep dan prinsip, (b) bertumpu pada kesepakatan atau konvensi, baik berupa simbol-simbol dan istilah maupun aturan-aturan dasar (aksioma), (c) berpola fikir deduktif, (d) konsisten dalam sistemnya, (e) memiliki simbol yang kosong dari arti, dan (f) memperhatikan semesta pembicaraan. (4) Karakteristik matematika di sekolah dapat dilihat pada aspek ; (a) penyajian, (b) pola fikir, (c) semesta pembicaraan, dan (d) tingkat keabstrakan.

David Paul Ausubel seorang tokoh ahli psikologi kognitif yang dilahirkan di New York pada tahun 1981. Menurut Ausubel (dalam Amalia. 2013), belajar dapat diklasifikasikan ke dalam dua dimensi. Dimensi pertama berhubungan dengan cara informasi atau materi pelajaran disajikan pada siswa, melalui penerimaan atau penemuan. Dimensi kedua menyangkut cara bagaimana siswa dapat mengaitkan informasi itu pada struktur kognitif yang telah ada. Struktur kognitif ialah fakta-fakta, konsep-konsep, dan generalisasigeneralisasi yang telah dipelajari dan diingat oleh siswa. kedua dimensi itu tidak menunjukkan dikotomi yang sederhana, tetapi lebih merupakan suatu kontinum, sebagai tampak pada bagan berikut. Menurutnya, belajar penerimaan tidak sama dengan belajar hapalan. Belajar penerimaan dapat dibuat bermakna, yaitu dengan cara menjelaskan hubungan antara konsep-konsep.

Struktur kognitif didefinisikan sebagai struktur organisasional yang ada dalam ingatan seseorang mengintegrasikan unsur-unsur pengetahuan yang terpisah kedalam suatu unit konseptual. Menurut Ausubel (dalam Amalia. 2013:2) Beberapa syarat yang harus dipenuhi agar belajar menjadi bermakna yaitu: Pengaturan awal (Advance organizer), Progressive differrentiation, Rekonsiliasi integratif, Konsolidasi. Inti teori Ausubel tentang belajar adalah belajar bermakna (meaningful learning). Belajar bermakna merupakan suatu proses untuk mengaitkan informasi baru dengan konsep-konsep relevan yang terdapat dalam struktur kognitif seseorang. Dalam menerapkan teori Ausubel dalam pembelajaran, guru dianjurkan untuk mengetahui terlebih dahulu kondisi awal siswa. hal ini sesuai dengan 
pandangan bahwa ada satu faktor yang sangat mempengaruhi belajar, yaitu pengetahuan yang telah diterima siswa.

\section{Menurut Thorndike belajar} adalah proses interaksi antara stimulus dan respon. Stimulus yaitu apa saja yang dapat merangsang terjadinya kegiatan belajar seperti pikiran, perasaan atau hal-hal lain yang dapat ditangkap melalui alat indra. Sedangkan respon yaitu reaksi yang dimunculkan peserta didik ketika belajar yang juga dapat berupa pikiran perasaan atau gerakan / tindakan. Dari definisi belajar tersebut maka menurut Thorndike perubahan tingkah laku akibat dari kegiatan belajar itu dapat berwujud konkret yaitu yang dapat diamati atau tidak konkret yang tidak dapat diamati. Sedangkan menurut Watson (dalam Budiningsih, 2012:220) belajar adalah proses interaksi antara stimulus dan respon, namun stimulus dan respon yang dimaksud harus berbentuk tingkah laku yang diamati dan dapat diukur. Sedangkan hasil belajar adalah kemampuankemampuan yang dimiliki siswa setelah ia menerima pengalaman belajar. Tiga macam hasil belajar, yaitu ; (1) keterampilan dan kebiasaan, (2) pengetahuan dan pengertian, (3) sikap dan cita-cita. Lima kategori hasil belajar yaitu ; (1) Informasi verbal, (2) Keterampilan intelektual, (3) Strategi kognitif, (4) Sikap, (5) Keterampilan motivasi.

Dalam sistem pendidikan nasional, rumusan tujuan pendidikan baik tujuan kurikuler maupun tujuan intruksional, menggunakan klasifikasi hasil belajar dari Benyamin Bloom, secara garis besar membagi hasil belajar menjadi tiga ranah, yaitu : ranah kognitif, ranah afektif dan ranah psikomotorik (Sudjana, 2005:22). Dari pendapat di atas dapat disimpulkan bahwa hasil belajar dalam penelitian ini adalah tingkat keberhasilan siswa dalam menguasai materi setelah proses pembelajaran dalam bentuk skor yang diperoleh siswa dari tes akhir tiap-tiap siklus yang telah diberikan dengan penerapan metode kerja kelompok. Membahas tentang hasil belajar tidak luput dari aktifitas belajar, Sebelum meninjau lebih jauh tentang aktifitas belajar, terlebih dahulu dijelaskan tentang aktifitas. Dalam Kamus Besar Bahasa Indonesia "Aktifitas berarti kesibukan, kegiatan, keaktifan, kerja atau suatu kegiatan kerja yang dilaksanakan pada tiap bagian dalam suatu peristiwa atau kejadian" (Moeliono, dkk, 2011:30).

Suryabrata (2004: 97) menyatakan, "Aktifitas adalah banyak sedikitnya orang yang menyatakan diri, menjelmakan perasaannya dan pikiran-pikirannya dalam tindakan yang spontan". Pembelajaran berorientasi pada aktifitas siswa yang dilihat dari prosesnya menghendaki keseimbangan antara aktifitas fisik, mental termasuk emosional dan aktifitas intelektualnya. Dari pendapat tersebut, maka dapat disimpulkan bahwa aktifitas adalah semua kegiatan yang dilakukan individu maupun kelompok untuk mengungkapkan pikiran-pikirannya dalam tindakan secara aktif atau pun segala kegiatan yang terjadi secara fisik maupun non fisik. Aktifitas belajar merupakan suatu kegiatan yang dilakukan untuk menghasilkan perubahan pengetahuan-pengetahu- 
an, nilai-nilai sikap, dan keterampilan pada siswa sebagai latihan yang dilaksanakan secara sengaja. Oemar Hamalik (2010:34), "aktifitas belajarmerupakan segala kegiatan yang dilakukan dalam proses interaksi (guru dan siswa) dalam rangka mencapai tujuan belajar".

Aktifitas yang dimaksudkan di sini penekanannya adalah pada siswa, sebab dengan adanya aktifitas siswa dalam proses pembelajaran akan tercipta situasi belajar aktif, seperti yang dikemukakan oleh Rochman Natawijaya (dalam Hamalik, 2010) menyatakan, "belajar aktif adalah suatu sistem belajar mengajar yang menekankan keaktifan siswa secara fisik, mental intelektual dan emosional guna memperoleh hasil belajar berupa perpaduan antara aspek kognitif, afektif dan psikomotor". Dari hal tersebut, dapat disimpulkan bahwa aktifitas belajar adalah serangkaian kegiatan yang saling berkaitan antara mentalitas siswa, fisik maupun kondisi pada saat pembelajaran yang melibatkan pengetahuan, nilai-nilai sikap, dan keterampilan siswa guna mencapai tujuan pembelajaran.

Menurut Paul D. Dierich (dalam Oemar Hamalik, 2001: 172) kegiatan-kegiatan yang merupakan aktifitas belajar adalah sebagai berikut : (a) Kegiatan-kegiatan visual: membaca, melihat gambargambar, mengamati, eksperimen, demonstrasi, pameran, mengamati orang lain bekerja, atau bermain (b) Kegiatan - kegiatan lisan (oral): mengemukakan suatu fakta atau prinsip, menghubungkan suatu kejadian, menyampaikan suatu pertanyaan, memberi saran, mengemukakan pendapat,

berwawancara, berdiskusi. (c) Kegiatan-kegiatan mendengarkan: mendengarkan penyajian bahan, mendengarkan percakapan atau diskusi kelompok, mendengarkan suatu permainan instrumen musik, mendengarkan siaran radio. (d) Kegiatan-kegiatan menulis: menulis cerita, menulis laporan, memeriksa karangan, membuat sketsa, mengerjakan tes, mengisi angket. (e) Kegiatan-kegiatan menggambar: meggambar, membuat grafik, dagram, peta, pola. (f) Kegiatankegiatan metric: melakukan percobaan, memilih alat-alat, melaksanakan pameranb, membuat model, menyelenggarakan permainan (simulasi), menari, berkebun. (g) Kegiatan-kegiatan mental: merenungkan, mengingat, memecahkan masalah, menganalisis faktor-faktor, menemukan hubungan-hubungan, membuat keputusan. (h) Kegiatankegiatan emosional: minat, membedakan, berani, tenang., dan sebagainya.

Abimayu (2008:24) mengemukakan keterlibatan pembelajaran dalam proses pembelajaran itu dapat berbentuk keterlibatan siswa yang dijelaskan sebagai berikut: (a) Keterlibatan fisik, seperti melakukan pengukuran, perhitungan, pengumpulan data, atau memperagakan suatu konsep dan lain-lain. (b) Keterlibatan mental. Dari pendapat Paul dan Soli Abimayu, dapat disimpulkan bahwa aktifitas belajar dapat dibedakan menjadi tiga yaitu, sebagai berikut : Aktifitas Fisik, Aktifitas fisik merupakan aktifitas atau kegiatan yang dialkukan siswa yang melibatkan gerak fisik seperti 
membaca, menulis, menyimak, menunjukkan, memperagakan, maju ke depan, dan lain-lain. Aktifitas Mental, Aktifitas mental merupakan suatu aktifitas atau kegiatan yang dilakukan siswa yang melibatkan kemampuan berfikir seperti mengajukan pertanyaaan, memberikan pendapat, berdiskusi, menyimpulkan dan lain-lain. Aktifitas Emosional, Aktifitas emosional merupakan suatu aktifitas atau kegiatan yang dilakukan siswa yang melibatkan emosi atau rasa seperti gembira belajar, semagat dalam belajar, menghargai pendapat teman, berani, kesungguhan dalam berdiskusi, dan lain-lain.

Think pair share merupakan salah satu tipe pembelajaran kooperatif yang dikembangkan oleh Frank Lyman, dkk dari Universitas Maryland pada tahun 1985 sebagai salah satu struktur kegiatan cooperative learning. Think pair share memberikan waktu kepada para siswa untuk berpikir dan merespon serta saling bantu satu sama lain. Think pair share memberi siswa kesempatan untuk bekerja sendiri serta bekerja sama dengan orang lain. Keunggulan lain dari pembelajaran ini adalah optimalisasi partisipasi siswa. Kagan dalam (Widarti :2007) menyatakan manfaat think pair share sebagai berikut: (1) Para siswa menggunakan waktu yang lebih banyak untuk mengerjakan tugasnya dan untuk mendengarkan satu sama lain, ketika mereka terlibat dalam kegiatan think pair share lebih banyak siswa yang mengangkat tangan mereka untuk menjawab setelah berlatih dalam pasangannya. Para siswa mungkin mengingat secara lebih seiring penambahan waktu tunggu dan kualitas jawaban mungkin menjadi lebih baik. (2) Para guru juga mempunyai waktu yang lebih banyak untuk berpikir ketika menggunakan think pair share. Mereka dapat berkonsentrasi mendengarkan jawaban siswa, mengamati reaksi siswa, dan mengajukan pertanyaan tingkat tinggi.

Teknik belajar mengajar think pair share mempunyai beberapa keuntungan sebagai berikut: (1) Mudah dilaksanakan dalam kelas yang besar, (2) Memberikan waktu kepada siswa untuk merefleksikan isi materi pelajaran, (3) Memberikan waktu kepada siswa untuk melatih mengeluarkan pendapat sebelum berbagi dengan kelompok kecil atau kelas secara keseluruhan. Dengan teknik belajar mengajar think pair share yang disebutkan Fogarty dan Robin siswa dilatih untuk banyak berfikir dan saling tukar pendapat baik dengan teman sebangku ataupun dengan teman sekelas, sehingga dapat meningkatkan hasil belajar ranah kognitif siawa karena siswa dituntut untuk mengikuti proses pembelajaran agar dapat menjawab setiap pertanyaan dan berdiskusi.

Ciri utama pada model pembelajaran kooperatif tipe think pair share adalah tiga langkah utamanya yang dilaksanakan dalam proses pembelajaran. Yaitu langkah think (berpikir secara individual), pair (berpasangan dengan teman sebangku), dan share (berbagi jawaban dengan pasangan lain atau seluruh kelas) Think (berpikir secara individual). Pada tahap think, guru mengajukan suatu pertanyaan atau masalah yang dikaitkan dengan pelajaran, dan siswa diminta untuk 
berpikir secara mandiri mengenai pertanyaan atau masalah yang diajukan. Pada tahapan ini, siswa sebaiknya menuliskan jawaban mereka, hal ini karena guru tidak dapat memantau semua jawaban siswa sehingga melalui catatan tersebut guru dapat mengetahui jawaban yang harus diperbaiki atau diluruskan di akhir pembelajaran. Dalam menentukan batasan waktu untuk tahap ini, guru harus mempertimbangkan pengetahuan dasar siswa untuk menjawab pertanyaan yang diberikan, jenis dan bentuk pertanyaan yang diberikan, serta jadwal pembelajaran untuk setiap kali pertemuan.Kelebihan dari tahap ini adalah adanya "think time" atau waktu berpikir yang memberikan kesempatan kepada siswa untuk berpikir mengenai jawaban mereka sendiri sebelum pertanyaan tersebut dijawab oleh siswa lain. Selain itu, guru dapat mengurangi masalah dari adanya siswa yang mengobrol, karena tiap siswa memiliki tugas untuk dikerjakan sendiri.

Pair (berpasangan dengan teman sebangku). Langkah kedua adalah guru meminta para siswa untuk berpasangan dan mendiskusikan mengenai apa yang telah dipikirkan. Interaksi selama periode ini dapat menghasilkan jawaban bersama. Biasanya guru mengizinkan tidak lebih dari 4 atau 5 menit untuk berpasangan. Setiap pasangan siswa saling berdiskusi mengenai hasil jawaban mereka sebelumnya sehingga hasil akhir yang didapat menjadi lebih baik, karena siswa mendapat tambahan informasi dan pemecahan masalah yang lain. Share (berbagi jawaban dengan pasangan lain atau seluruh kelas). Pada langkah akhir ini guru meminta pasangan-pasangan tersebut untuk berbagi hasil pemikiran mereka dengan pasangan lain atau dengan seluruh kelas. Pada langkah ini akan menjadi efektif jika guru berkeliling kelas dari pasangan satu ke pasangan yang lain, sehingga seperempat atau separuh dari pasangan-pasangan tersebut memperoleh kesempatan untuk melapor. Langkah ini merupakan penyempurnaan dari langkahlangkah sebelumnya, dalam arti bahwa langkah ini menolong agar semua kelompok menjadi lebih memahami mengenai pemecahan masalah yang diberikan berdasarkan penjelasan kelompok yang lain. Hal ini juga agar siswa benar-benar mengerti ketika guru memberikan koreksi maupun penguatan di akhir pembelajaran.

Menurut teori konstruktivisme, siswa sebagai pemain dan guru sebagai fasilitator. Guru mendorong siswa untuk mengembangkan potensi secara optimal. Siswa belajar bukanlah menerima paket-paket konsep yang sudah dikemas oleh guru, melainkan siswa sendiri yang mengemasnya. Bagian terpenting dalam teori konstruktivisme adalah bahwa dalam proses pembelajaran, siswalah yang harus aktif mengembangkan kemampuan mereka, bukan guru atau orang lain. Mereka harus bertanggung jawab terhadap hasil belajarnya.

\section{Metode}

Penelitian yang dilakukan merupakan Penelitian Tindakan Kelas (PTK). PTK merupakan suatu studi sistematik terhadap praktik 
pembelajaran di kelas yang bertujuan untuk memperbaiki atau meningkatkan kualitas proses dan hasil belajar dengan melakukan tindakan tertentu. Dalam penelitian ini para siswa dikenai tindakan, yaitu berupa pembelajaran dengan menggunakan model pembelajaran kooperatif tipe think-pair-share.

Arikunto (2009:2) menyatakan Penelitian Tidakan Kelas harus menyangkut upaya guru dalam bentuk proses pembelajaran dan yang terpenting adalah peningkatan hasil belajar siswa. Penelian ini bertujuan meningkatkan hasil belajar siswa, oleh karena itu metode penelitian yang digunakan adalah metode deskriptif, dengan jenis kolaboratif partisipatoris yaitu partisipasi antara peneliti dan guru mata pelajaran atau teman sejawat. Dalam PTK ini peneliti selaku pelaksana pembelajaran sedangkan guru mata pelajaran atau teman sejawat membantu mengamati jalannya pembelajaran.

Penelitian ini dilaksanakan di kelas X E Sekolah Menengah Atas Negeri 1 Sungai Raya Kabupaten Kubu Raya. Pada tindakan kelas ini yang menjadi subjek penelitian adalah sebagai berikut : (a) Siswa kelas X E Sekolah Menengah Atas Negeri 1 Sungai Raya Kabupaten Kubu Raya dengan jumlah siswa laki-laki 11 orang dan jumlah siswa perempuan 17 orang. (b) Guru sebagai peneliti yang melaksanakan penelitian tindakan kelas di kelas $\mathrm{X}$ Sekolah Menengah Atas Negeri 1 Sungai Raya Kabupaten Kubu Raya. Menurut

Suhardjono (2009:70), PTK mencakup empat langkah, yaitu: (1) perencanaan (planning), (2) tindakan (acting), (3) pengamatan (observing), (4) evaluasi atau refleksi (reflecting). Keempat langkah tersebut bersifat spiral dan dipandang sebagai satu siklus. Gambaran umum dari Penelitian Tindakan Kelas ini tergambar dalam Spiral Penelitian Tindakan Kelas (Arikunto, 2009:16).

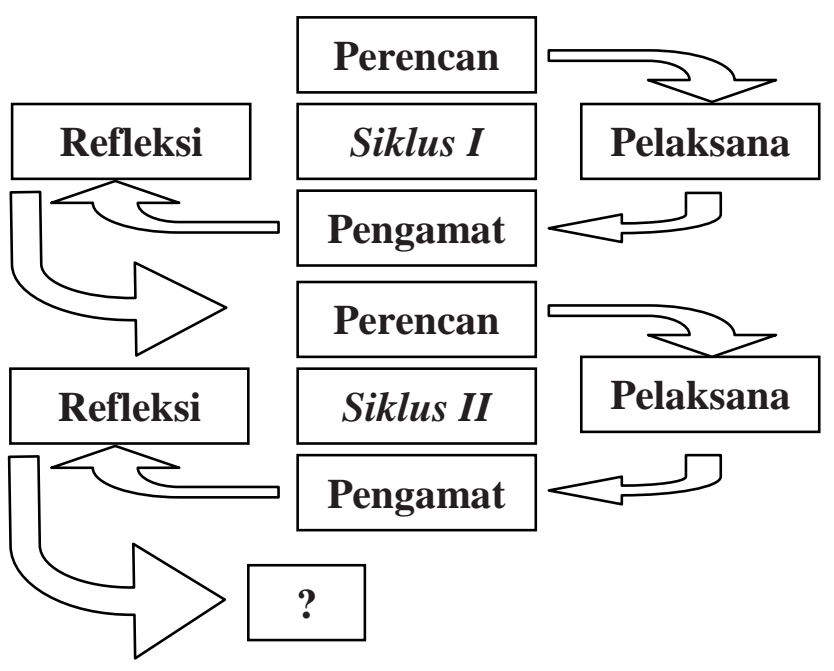

Gambar 1. Spiral PTK

Secara rinci prosedur penelitian tindakan ini dapat dijabarkan sebagai berikut:

1. Siklus I

Perencanaan Tindakan.

Kegiatan yang dilaksanakan pada tahap perencanaan tindakan adalah menyusun rancangan yang akan dilaksanakan, sesuai dengan temuan masalah dan gagasan awal. Dalam perencanaan ini peneliti mengembangkan rencana pembelajaran, lembar observasi, di bawah bimbingan dosen. Pembuatan rencana pembelajaran dan soal evaluasi dikonsultasikan dengan guru sejawat.

Pelaksanaan Tindakan, Pada tahap ini, guru melaksanakan yang telah direncanakan. Dalam usaha 
kearah perbaikan suatu perencanaan bersifat fleksibel dan siap dilakukan perubahan sesuai apa yang terjadi dalam proses pelaksanaan di lapangan.

Observasi. Pada tahap ini hal yang dilakukan selama pembelajaran berlangsung ini sebagai upaya dalam mengamati pelaksanaan tindakan. Dalam melakukan observasi, peneliti dibantu pengamat lain yang turut dalam mengamati jalannya pembelajaran berdasarkan lembar observasi keaktifan siswa yang telah disiapkan oleh peneliti.

Refleksi. Pada tahap ini peneliti berdiskusi dengan guru mengenai hasil pengamatan yang dilakukan selama pembelajaran. Refleksi bertujuan untuk mengetahui kekurangan dan kelebihan yang terjadi saat pembelajaran berlangsung. Hasil dari diskusi yang dilakukan akan digunakan sebagai pertimbangan dalam merencanakan pembelajaran siklus berikutnya.

\section{Siklus II}

Kegiatan-kegiatan yang dilakukan pada siklus II dimaksudkan sebagai perbaikan terhadap pelaksanaan pembelajaran pada siklus I. Prosedur pelaksanaan pembelajaran pada siklus II sama dengan siklus I yaitu diawali dari perencanaan, pelaksanaan tindakan, observasi dan refleksi. Perencanaan tindakan pada siklus II dilakukan oleh peneliti dan guru dengan berdasarkan pada hasil refleksi pada siklus I. apabila perubahan yang bertujuan meningkatkan kualitas pembelajaran telah tercapai, atau apa yang diteliti telah menunjukkan keberhasilan, siklus dapat diakhiri.

Teknik pengumpulan data yang dilakukan pada penelitian ini adalah dengan teknik observasi langsung dan pengukuran. Teknik observasi merupakan teknik pengumpulan data dari hasil pengamatan yang dilakukan oleh peneliti, khususnya terhadap pelaksanaan kegiatan pembelajaran yang dilakukan oleh peneliti. Teknik pengukuran digunakan untuk melihat hasil belajar siswa. Lembar observasi digunakan untuk mengukur kemampuan guru dalam menggunakan media gambar pada pembelajaran dan aktifitas belajar siswa dalam prosespembelajaran matematika.Soal-soal merupakan alat pengumpul data untuk mengetahui tingkat keberhasilan siswa dalam proses pembelajaran. Soal-soal akan diberikan diakhir proses pembelajaran.

Pada umumnya analisis kualitatif terhadap data PTK dapat dilakukan dengan tahap-tahap: menyeleksi, menyederhanakan, mengklasifikasi, memfokuskan, mengorganisasi (mengaitkan gejala secara sistematis dan logis), membuat abstraksi atas kesimpulan makna hasil analisis.

Model analisis kualitatif yang terkenal adalah model Miles \& Hubberman (dalam Mulyatiningsih, 2012:5) yang meliputi : reduksi data (memilah data penting, relevan, dan bermakna dari data yang tidak berguna), sajian deskriptif (narasi, visual gambar, tabel) dengan alur sajian yang sistematis dan logis, penyimpulan dari hasil yg disajikan (dampak PTK dan efektivitasnya). 
Model analisis ini dapat digambarkan pada Gambar 2.

Skor hasil belajar siswa diubah kedalam bentuk persentase dan diubah berdasarkan pedoman pengubahan data kuantitatif ke kualitatif Robert Ebel L. (dalam Asriani, 2012:33).

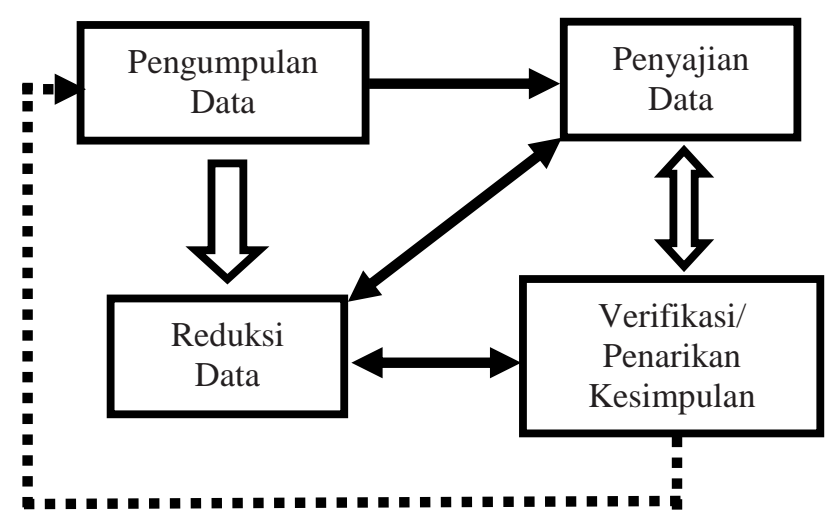

Gambar 2. Bagan Analisis Kualitatif Tabel 2. Konversi Data Kuantitatif ke Kualitatif

\begin{tabular}{cc}
\hline $\begin{array}{c}\text { Persentase } \\
\text { (Kuantitatif) }\end{array}$ & $\begin{array}{c}\text { Kriteria } \\
\text { (Kualitatif) }\end{array}$ \\
\hline $81-100$ & Sangat tinggi \\
\hline $71-80$ & Tinggi \\
\hline $61-70$ & Sedang \\
\hline $40-60$ & Rendah \\
\hline $0-19$ & Sangat rendah \\
\hline
\end{tabular}

Untuk mengetahui berhasil tidaknya tindakan yang telah dilaksanakan dengan berdasar pada rencana tindakan yang ditetapkan, maka kriteria yang digunakan adalah bersumber dari tujuan dilakukannya tindakan. Adapun tujuan pelaksanaan tindakan dalam penelitian ini adalah untuk memperbaiki dan meningkatkan pembelajaran matematika siswa kelas X Sekolah Menengah Atas Negeri 1 Sungai Raya Kabupaten Kubu Raya. Kriteria yang dijadikan tolok ukur keberhasilan tindakan adalah pencapaian ketuntasan belajar klasikal minimal $70 \%$ jumlah siswa yang tuntas dengan standar ketuntasan belajar 70 .

\section{Hasil dan Pembahasan}

Sebagai tes awal peneliti mengambil materi logaritma. Hasil ulangan pertama (I) nilai tertinggi 92 dan nilai terendah 20 , sedang rataratanya 55,3. Hasil ulangan ke dua (II) sudah agak meningkat sedikit yaitu nilai tertingi 96 dan nilai terendah 20 sedang rata-ratanya 64,8 . Ulangan pertama (I) berbentuk uraian terdiri dari 5 soal, sedangkan ulangan kedua (II) berbentuk uraian dengan jumlah 5 soal. Dari hasil ulangan kondisi awal rata-rata nilai nya adalah 60,1 . Dari hasil ulangan tersebut dibuat Tabel 3.

Tabel 3. Nilai Ulangan Harian Kondisi Awal

\begin{tabular}{cccc}
\hline \multirow{2}{*}{ No } & \multirow{2}{*}{ Uraian } & \multicolumn{2}{c}{ Kondisi Awal } \\
\cline { 3 - 4 } & & $\begin{array}{c}\text { Ulangan } \\
\text { Harian I }\end{array}$ & Ulangan \\
& & 92,0 & 96,0 \\
\hline 1 & Nilai Tertinggi II & 96,0 \\
2 & Nilai Terendah & 20,0 & 20,0 \\
3 & Rata-rata & 55,3 & 64,8 \\
\hline
\end{tabular}

Rata-rata ulangan pada kondisi awal adalah 60,1. Setelah melalui proses identifikasi materi, telah ditetapkan Kreteria Ketuntasan Minimal (KKM)siswa SMA Negeri 1 Sungai Raya Kabupaten Kubu Raya untuk tahun pelajaran 2013/2014, kelas X adalah 70. Dari hasil ulangan pada kondisi awal tampak bahwa banyak siswa yang tuntas dan belum tuntas dapat dilihat pada Tabel 4.

Hasil penelitian tindakan kelas pada siklus I, dapat dilihat pada Tabel 5. 
Tabel 4. Prosentase Ketuntasan Ulangan Harian Kondisi Awal

\begin{tabular}{|c|c|c|c|c|c|}
\hline \multirow[t]{2}{*}{ No } & \multirow[t]{2}{*}{ Uraian } & \multicolumn{2}{|c|}{$\begin{array}{l}\text { Ulangan } \\
\text { Harian I }\end{array}$} & \multicolumn{2}{|c|}{$\begin{array}{c}\text { Ulangan } \\
\text { Harian II }\end{array}$} \\
\hline & & Jlh & $\%$ & $\mathrm{Jlh}$ & $\%$ \\
\hline 1 & Tuntas & 8 & 28,57 & 9 & 32,15 \\
\hline 2 & $\begin{array}{l}\text { Tidak } \\
\text { Tuntas }\end{array}$ & 20 & 71,43 & 19 & 67,85 \\
\hline
\end{tabular}

Tabel 5. Hasil Tes Akhir Siklus I

\begin{tabular}{clc}
\hline No & Komponen & $\begin{array}{c}\text { Hasil Tes Akhir } \\
\text { Siklus I }\end{array}$ \\
\hline 1 & Nilai Tertinggi & 96,0 \\
2 & Nilai Terendah & 52,0 \\
3 & Rata-rata & 72,0 \\
\hline
\end{tabular}

Dari hasil pengamatan siklus I diperoleh rata-rata nilai adalah 72,0 , jumlah siswa tuntas 13 orang dan yang belum tuntas 15 orang. Hasil belajar yang diperoleh siswa kelas $\mathrm{X}$ $\mathrm{E}$ sudah ada peningkatan sebesar 20,3\% dibanding dengan kondisi awal. Pada siklus I proses pembelajaran belum optimal dikarenakan siswa masih belum terkondisi dengan kelompok yang baru saja dibentuk dan belum terbiasa dengan model diskusi hanya siswa-siswa tertentu saja yang bisa aktif mengikuti jalannya diskusi. Sehingga harus ada perbaikanperbaikan khususnya dalam pengelolaan perjalanan diskusi.

Hasil pengamatan tentang proses pembelajaran belum kelihatan optimal, ini dikarenakan masih adanya siswa yang mempunyai egoisme yang tinggi, sehingga jika bertemu dengan pasangan yang tidak cocok terus proses sehingga pembelajaran kurang efektif. Yang lebih pintar merasa kurang berguna dan siswa yang merasa kurang pintar sungkan untuk menanyakan materi . Ini semua karena belum biasa dengan proses pembelajaran dengan pendekatan think pair share. Siswa yang demikian peneliti perhatikan dan dipantau, selalu dimotivasi untuk ikut aktif dalam proses diskusi. Hasil pengamatan ada beberapa siswa yang tidak aktif, dan jika diklasifikasi tampak seperti yang tertuang dalam Tabel 6.

Dari hasil pengamatan dalam proses pembelajaran tampak bahwa masih ada siswa yang acuh tak acuh dan ada siswa yang merasa tidak nyaman dengan metode pembelajaran demikian, hal ini disebabkan karena perhatian guru belum optimal sebab masih terfokus pada bagaimana cara berganti pasangan.

Tabel 6. Hasil Pengamatan Tentang Keadaan SiswaPada Proses Pembelajaran Siklus I.

\begin{tabular}{clcc}
\hline No & \multicolumn{1}{c}{ Keadaan siswa } & Jlh & $\%$ \\
\hline 1 & Sungguh sungguh/ aktif & 22 & 78,6 \\
2 & Biasa & 3 & \\
3 & Acuh tak acuh & 2 & \\
4 & Tidak nyaman & 1 & \\
\hline & Jumlah & 28 & \\
\hline
\end{tabular}

Pada akhir siklus I dapat disimpulkan bahwa aktifitas siswa maupun hasil belajar siswa sudah mengalami peningkatan dibandingkan dengan kondisi awal walaupun belum memenuhi kreteria keberhasilan yang diharapkan. Hal ini disebabkan pembelajaran dengan teknik think pair share belum memenuhi kondisi yang diharapkan, guru belum optimal dalam pengolaan kelompok pembelajaran siswa. Siswa juga masih belum familier dengan teknik yang digunakan oleh guru. Dari guru sendiri juga masih belum terbiasa dengan pendekatan pembelajarn dengan teknik think pair share. Oleh karena itu perlu dilakukan perbaikan untuk lebih 
meningkatkan hasil belajar maupun aktifitas siswa melalui pendekatan think pair share.

Kelemahan itu antara lain ; Dari peneliti (guru) (a) peneliti kurang memotivasi pentingnya dalam kerja sama dalam kelompok, (b) Peneliti belum dapat mengelola waktu dengan baik dalam proses pembelajaran. Sedang dari siswa (a) siswa masih banyak yang ribut dalam berganti pasangan, (b) siswa kurang aktif dalam memberikan saran atau usulan dalam kelompok, kebanyakan siswa masih ikut pendapat salah satu teman yang diangap bisa. Perbaikan yang harus dilakukan adalah: (a) Guru harus banyak memotivasi siswa bahwa kerjasama dalam kelompok adalah sangat penting, (b) pengelolaan waktu harus lebih baik.

Hasil penelitian tindakan kelas pada siklus II, dapat dilihat hasil tes siklus II sebagai berikut:

\begin{tabular}{ccc}
\multicolumn{2}{c}{ Tabel 7. Hasil Tes } & Akhir Siklus II \\
\hline No & Komponen & $\begin{array}{c}\text { Hasil Tes Akhir } \\
\text { Siklus II }\end{array}$ \\
\hline 1 & Nilai Tertinggi & 100,0 \\
2 & Nilai Terendah & 68,0 \\
3 & Rata-rata & 81,6 \\
\hline
\end{tabular}

Dari hasil pengamatan siklus II diperoleh rata-rata nilai adalah 81,6 , jumlah siswa tuntas 25 orang dan yang belum tuntas 3 orang. Hasil belajar yang diperoleh siswa kelas $\mathrm{X}$ E mengalami peningkatan sebesar $35,7 \%$ dibanding dengan kondisi awal. Pada siklus II masih ada siswa yang belum tuntas, meskipun demikian secara keseluruhan proses pembelajaran telah berjalan sesuai dengan rencana pembelajaran yang telah dibuat.
Hasil pengamatan tentang proses pembelajaran terlihat cukup optimal, ini dikarenakan siswa maupun guru sudah tidak merasa asing lagi terhadap metode pembelajaran yang baru yaitu model pembelajaran kooperatif tipe Think Pair Share (TPS). Siswa secara keseluruhan aktif dan antusias dalam setiap kegiatan pembelajaran karena guru lebih memotivasi siswa untuk memacu semangat belajar mereka. Hasil pengamatan proses pembelajaran dapat dilihat pada Tabel 8.

Dari hasil pengamatan meski masih ada siswa dengan kategori biasa. Tetapi mereka tidak luput dari turut melakukan aktifitas diskusi bersama disaat proses belajar berlangsung dan terlihat suasana kompetisi yang sehat diantara siswa membuat suasana belajar begitu bersemengat.

Tabel 8. Hasil Pengamatan Tentang Keadaan SiswaPada Proses Pembelajaran Siklus II

\begin{tabular}{clcc}
\hline No & Keadaan siswa & Jlh & $\%$ \\
\hline 1 & Sungguh sungguh/ & 24 & 85,7 \\
& aktif & & \\
2 & Biasa & 4 & \\
3 & Acuh tak acuh & 0 & \\
4 & Tidak nyaman & 0 & \\
\hline & Jumlah & 28 & \\
\hline
\end{tabular}

Pada akhir siklus II dapat disimpulkan bahwa aktifitas siswa maupun hasil belajar siswa sudah sesuai dengan hasil yang diharapkan. Guru secara optimal dalam mengatur jalannya proses kegiatan belajar mengajar sesuai dengan rencana pembelajaran yang telah disusun, siswa dengan semangat dan motivasi yang tinggi melakukan semua instruksi dengan baik dan benar 
sehingga berdampak pada prestasi belajar mereka yang meningkat. Sehingga peneliti tidak lagi melanjutkan siklus berikutnya dalam penelitian ini.

Secara teoritis menyatakan bahwa, pembelajaran dengan pendekatan Think Pair Share dapat meningkatkan hasil belajar siswa Pokok Bahasan Logaritma X E SMA Negeri 1 Sungai Raya Kabupaten kubu Raya Tahun Ajaran 2013/2014. Dari hasil penelitian diketahui bahwa aktifitas siswa pada siklus I rata-rata keaktifan siswa 78,6 \% sedang pada siklus II keaktifan rata-rata siswa adalah $85,7 \%$.

Kondisi awal pada Ulangan harian I diperoleh nilai tertinggi 92 terendah 20 dan rata-ratanya 55,3. Kondisi awal pada ulangan harian II diperoleh nilai tertinggi 96 terendah 20 dan rata-ratanya 64,8 . Hasil tes akhir setelah ada tindakan pada siklus I adalah sebagai berikut Nilai tertinggi 96 terendah 52 dan rataratanya 72. Jika diprosentase perkembangan rata-rata nilai adalah untuk kondisi awal ke kondisi siklus I sebesar 19,8 \%, dan dari kondisi siklus I ke kondisi siklus II rata-rata nilai meningkat sebesar 13,3\%. Jadi dari kondisi awal ke kondisi setelah siklus II nilai rata-rata nya dapat meningkat sebesar 35,7 \%. Jadi dapat disimpulkan bahwa pembelajaran dengan model pembelajaran kooperatif tipe Think Pair Share dapat meningkatkan hasil belajar matematika sekaligus meningkatkan aktifitas belajar pada kelas X tahun pelajaran 2013/2014.

\section{Simpulan dan Saran}

Hasil dari penelitian ini adalah perkembangan rata-rata nilai adalah untuk kondisi awal ke kondisi siklus I sebesar 19,8 \%, dan dari kondisi siklus I ke kondisi siklus II rata-rata nilai meningkat sebesar 13,3\%. Jadi dari kondisi awal ke kondisi setelah siklus II nilai ratarata nya dapat meningkat sebesar $35,7 \%$.Secara umum dapat disimpulkan bahwa upaya meningkatkan penguasaan materi logaritma melalui model pembelajaran kooperatif tipe think pair share pada siswa kelas X SMA Negeri 1 Sungai Raya sesuai dengan apa yang diharapkan yaitu siswa menjadi lebih aktif dan prestasi belajarnya meningkat.

Agar proses dan hasil belajar lebih maksimal, disarankan proses pembelajaran yang dirancang guru harus dapat melibatkan siswa secara aktif, bukan hanya secara fisik tetapi juga secara mental dan emosional.

Daftar Pustaka

Abimayu, Soli. (2008).Strategi Pembelajaran. Jakarta: Depdiknas.

Amalia. (2013). Teori Belajar Bermakna Dari Davi P. Ausubel. Jakarta: Universitas Terbuka.

Arikunto, Suharsimi. (2009). Classroom Action Research-CAR. Jakarta : Bumi Aksara

Asep. (2011). Pembentukan Karakter Bangsa Dalam Pembelajaran Persamaan Eksponen dan Logaritma Berbasis Proses Abbstraksi. Bandung : Universitas Pendidikan Indonesia. 
35 Jurnal Pendidikan Matematika dan IPA Vol. 4. No. 2. Januari 2013: 22-35

Asriani. (2012). Peningkatan Pembelajaran Matematika Tentang Waktu Dengan Media Gambar Pada Siswa Kelas II Sekolah Dasar Negeri 2. Pontianak : PGSD-UNTAN.

Budiningsih, Asri. (2012). Belajar dan Pembelajaran. Jakarta : Rineka Cipta.

Depdiknas. (2007). Kajian Kebijakan Kurikulum Mata Pelajaran Matematika. Jakarta : Depdiknas BPDP Puskur.

Fadholi, Arif. (2009). Kelebihan dan Kekuragan Kooperatif Tipe Think Pair Share. (ariffadholi.blogspot.com/2 009/10/kelebihankekurangan-tps.html. diakses tanggal 25 Juni 2014)

Hamalik, Oemar. (2010). (Online). (http://id.shvoong.com/tags/ pengertian-aktivitas-belajarmenurut-oemar-hamalik/ diakses pada tanggal 4 Agustus 2013).

Mulyatiningsih. (2012). Metode Penelitian Terapan Bidang Pendidikan. Bandung : Alfa Beta

Mulyono, Anton M. Dkk. (2001). Hakikat Akrivitas (Online) (Http edukasi.
Kompasiana.com, diakses 20 September 2013).

Sudjana, Nana. (2005). Dasar-dasar Proses Belajar Mengajar. Bandung : Sinar Baru.

Suhardjono. (2009). Penelitian Tindakan Kelas Sebagai Kegiatan Pengembangan Profesi Guru. Jakarta : Bumi Aksara

Sumardyono. (2004). Karakteristik Matematika Dalam Implikasinya Terhadap Pembelajaran Matematika. Yogyakarta : Dirjen P4MTK.

Suryabrata, Sumadi. (2004). Psikologi Pendidikan. Yogyakarta: Rajawali.

Trianto. (2010). Mendesain Model Pembelajaran InovatifProgresif. Jakarta : Kencana Prenada Media Group.

Wirdati, Atik. (2007). Efektifitas Penggunaan Model Pembelajaran Kooperatif Tipe Think Pair Share Terhadap Hasil Belajar Pokok Bahasan Segi Empat Pada Siswa Kelas VII Semester 2. Semarang : Universitas Semarang. 